\title{
Use of phytase at graded levels for improving nutrient digestibility, growth and hematology of Catla catla fingerlings fed Moringa oleifera seed meal (MOSM) based diet
}

\author{
SYED MAKHDOOM HUSSAIN ${ }^{1}$, MUHAMMAD MUDASSAR SHAHZAD ${ }^{1}$, \\ NOSHEEN ASLAM ${ }^{2}$, ARSHAD JAVID ${ }^{3}$, ABDULLAH IJAZ HUSSAIN ${ }^{4}$, MAJID HUSSAIN ${ }^{5}$ \\ AND MUHAMMAD ZUBAIR-UL-HASSAN ARSALAN ${ }^{1}$ \\ ${ }^{1}$ Fish Nutrition Lab, Department of Zoology, Government College University, Faisalabad, Pakistan \\ ${ }^{2}$ Department of Applied Chemistry and Biochemistry, Government College University, Faisalabad, Pakistan \\ ${ }^{3}$ Department of Wildlife and Ecology, University of Veterinary and Animal Sciences, Lahore, Pakistan \\ ${ }^{4}$ Department of Chemistry, Government College University, Faisalabad, Pakistan \\ ${ }^{5}$ Department of Zoology, University of Gujrat, Gujrat, Pakistan \\ e-mail:drmakhdoom90@gmail.com
}

\begin{abstract}
Present research work was conducted to evaluate the effect of phytase supplementation on nutrient digestibility, growth performance and hematological indices of Catla catla (Hamilton, 1822) fingerlings fed Moringa oleifera seed meal (MOSM) based diet. Existence of phytate in plant byproducts decreases the bioavailability of nutrients to fish, resulting in low nutrients availability, poor fish growth and hematological indices in fish body. Moringa byproducts such as M. oleifera seed meal (MOSM) was used as test ingredient to formulate experimental diet. Experimental diet was divided into six test diets and were supplemented with graded levels $\left(0,300,600,900,1200\right.$ and $\left.1500 \mathrm{FTU} \mathrm{kg}^{-1}\right)$ of phytase. The fingerlings were fed at the rate of $4 \%$ of live wet weight twice a day in V-shaped indoor tanks. Phytase supplementation showed significant $(p<0.05)$ improvement in bioavailability of nutrients, growth indices and hematological parameters. Results showed that maximum growth performance, digestibility of nutrients and improved hematological values of $C$. catla fingerlings were noted at $900 \mathrm{FTU} \mathrm{kg}^{-1}$ level of phytase supplementation in MOSM based test diet. It was concluded that phytase supplementation at $900 \mathrm{FTU} \mathrm{kg}^{-1}$ level was helpful to develop an eco-friendly and cost effective fish feed incorparating moringa seed meal.
\end{abstract}

Keywords: Catla catla, Growth, Hematology, Moringa oleifera seed meal, Nutrient digestibility, Phytase

\section{Introduction}

Catla catla (Hamilton, 1822) commonly known as 'thaila', is a surface feeder being cultured widely along with other freshwater fish species in Pakistan (Aslam et al., 2016). Production of this species increased during the first decade of $21^{\text {st }}$ century and in 2012, world production was about 2.8 million $\mathrm{t}$ (FAO, 2015). Demand for fish consumption is constantly increasing as a source of food and for health benefits (Abdulkadir et al., 2016; Tiamiyu et al., 2016). Fishmeal is a major source of protein used in formulation of feed for different fish species as it contains important vitamins, attractants, nutrients, fatty acids and amino acids (Dawood et al., 2015). However, unstable supply, higher demand and increasing cost of fish meal led to search for alternative cost effective sources of protein (Hardy, 2010; Lim et al., 2011). The best alternative protein sources are plant byproducts because of their low cost and easy availability throughout the year. A number of researchers have found positive effects on fish growth and nutrient digestibility when different fish species were fed plant byproducts based diets (Hussain et al., 2015a; Liu et al., 2017). One of the cost effective plant protein sources is Moringa oleifera (family Moringaceae) known as miracle tree (Yuangsoi et al., 2014) and locally called 'sohanjana' or 'sanjana' in Pakistan and found common in southern Punjab. M. oleifera seed meal (MOSM) is a good source of protein (33 to 38\%), important vitamins, essential amino acids viz., methionine, cystine and tryptophan (Makkar and Becker, 1996). M. oleifera seed is also virtuous source of protein, fat as well as other nutrients. However, MOSM contains the anti-nutritional factor phytate or phytic acid (Worku, 2016). Presence of phytate in plant based diets can cause adverse effects on nutrient digestibility in fish (Hussain et al., 2015a, b). Moreover, it is capable of binding with essential amino acids in different fish species that decreases bioavailability of nutrients, especially protein (Usmani and Jafri, 2002). Further, growth and hematological parameters are also adversely 
affected by higher concentrations of phytate/phytic acid in plant byproducts or oilseed meals based diets (Cao et al., 2007). Chelated phosphorous cannot be utilised by mono-gastric fishes, resulting in increased nutrient discharge into water media causing aquatic pollution (NRC, 1993). Phytate complex can be broken down only by some enzymatic reactions because it is a stable compound (Vielma et al., 2000). Phytase, chemically known as myo-inositol hexa-kisphosphatephospho-hydrolase, belongs to class III hydrolases. Supplemental dietary phytase is an effective method to improve the nutrients availability and feed conversion ratio (FCR) of fish. It also decreases water pollution by proper digestion and absorption of nutrients in fish body (Hussain et al., 2011; Liu et al., 2013; Hussain et al., 2015a). It was noted that growth parameters of Indian major carps was significantly decreased when phytic acid was incorporated in feed (Alvi, 1994). Phytase supplementation improved growth performance and nutrient digestibility of Labeo rohita fed on plant byproducts based diets (Baruah et al., 2007a; Hussain et al., 2015b). The purpose of the present study was to examine the effects of phytase supplementation on nutrient digestibility, growth performance and hematological indices of $C$. catla fingerlings fed MOSM based diets.

\section{Materials and methods}

The experiment was conducted in the Fish Nutrition Laboratory, Department of Zoology, Government College University Faisalabad, Pakistan.

\section{Fish and experimental conditions}

C. catla fingerlings were procured from the government Fish Seed Hatchery, Satiana Road, Faisalabad. Prior to initiation of the experiment, fingerlings were acclimatised to the laboratory conditions for fourteen days in specially designed V-shaped tanks having 701 water holding capacity. During this period, the fingerlings were fed once daily on basal diet (Allan and Rowland, 1992). Water quality parameters such as temperature, $\mathrm{pH}$ and dissolved oxygen (DO) were monitored on daily basis. Air pump was used for aeration by capillary system throughout the experimental period. Before starting experimental feeding, C. catla fingerlings were treated for 1 to $2 \mathrm{~min}$ with $0.5 \%$ saline solution to remove the pathogens if any present (Rowland and Ingram, 1991).

\section{Experimental design}

M. oleifera seed meal (MOSM) was used as the major protein source in the basal diet. Six test diets were prepared by supplementing the basal diet with graded levels $\left(0,300,600,900,1200\right.$ and $\left.1500 \mathrm{FTU} \mathrm{\textrm {kg } ^ { - 1 }}\right)$ of phytase enzyme. The diets were fed to six groups of fishes, with each group having triplicate tanks, each stocked with 15 fingerlings per tank $\left(8.06 \pm 0.042 \mathrm{~g} \mathrm{fish}^{-1}\right)$. Duration of the experiment was 90 days.

Processing of $M$. oleifera seeds and preparation of experimental diets

M. oleifera seeds were obtained from local market in Faisalabad. Seeds were air dried and defatted by press method (Weiss, 1971; Salem and Makkar, 2009). Processed moringa seeds were ground to powder.

The feed ingredients procured from local commercial market, finely ground and passed through $0.3 \mathrm{~mm}$ sieve size (Table 1). Prior to the formulation of the experimental diets, the feed ingredients were analysed for proximate composition (Table 2) following standard methods

Table 1. Ingredients composition (\%) of control and test diets (Dry matter basis)

\begin{tabular}{|c|c|c|c|c|c|c|}
\hline Ingredients & Test diet I (Control) & Test diet II & Test diet III & Test diet-IV & Test diet $\mathrm{V}$ & Test diet VI \\
\hline MOSM & 35 & 35 & 35 & 35 & 35 & 35 \\
\hline Fish meal & 15 & 15 & 15 & 15 & 15 & 15 \\
\hline Soybean meal & 15 & 15 & 15 & 15 & 15 & 15 \\
\hline Rice polish & 8 & 8 & 8 & 8 & 8 & 8 \\
\hline Wheat flour* & 17 & 17 & 17 & 17 & 17 & 17 \\
\hline Fish oil & 6 & 6 & 6 & 6 & 6 & 6 \\
\hline Vitamin premix ${ }^{* *}$ & 1.0 & 1.0 & 1.0 & 1.0 & 1.0 & 1.0 \\
\hline Chromic oxide & 1.0 & 1.0 & 1.0 & 1.0 & 1.0 & 1.0 \\
\hline Ascorbic acid & 1.0 & 1.0 & 1.0 & 1.0 & 1.0 & 1.0 \\
\hline Mineral mixture ${ }^{* * * *}$ & 1.0 & 1.0 & 1.0 & 1.0 & 1.0 & 1.0 \\
\hline Phytase level (FTU kg-1) & 0 & 300 & 600 & 900 & 1200 & 1500 \\
\hline
\end{tabular}

MOSM $=$ M. oleifera seed meal

* Phytase enzyme was used at the expense of wheat flour

*** Vitamin premix per kg: Vitamin $\mathrm{D}_{3}:$ 3,000,000 IU, Vitamin A: 15,000,000 IU, Vitamin E: 30000 IU, Vitamin B: 3000 mg, Vitamin B: 4000 mg,

Vitamin $\mathrm{B}_{12}: 40 \mathrm{mg}$, Vitamin $\mathrm{B}_{2}: 7000 \mathrm{mg}$, Vitamin C: 15,000 mg, Vitamin $\mathrm{K}_{3}: 8000 \mathrm{mg}$, Folic acid: $1500 \mathrm{mg}$, Calcium pantothenate: $12,000 \mathrm{mg}$, Nicotinic acid: 60,000 mg.

${ }^{* * * *}$ Mineral premix per kg: Mn (Manganese): 2000 mg, Ca (Calcium): 155 g, Zn (Zinc): 3000 mg, Cu: (Copper), $600 \mathrm{mg}, \mathrm{Co}:(\mathrm{Cobalt}), 40 \mathrm{mg}$, I (Iodine): 40 mg, P (Phosphorous): 135 g, Fe (Iron): 1000 mg, Mg (Magnesium): 55 g, Se (Selenium): 3 mg, Na (Sodium): 45 g. 
Table 2. Proximate composition (\%) of feed ingredients (Dry matter basis)

\begin{tabular}{llllll}
\hline Parameter & MOSM & Fish meal & Rice polish & Wheat flour & Corn gluten meal 60\%) \\
\hline Dry matter (\%) & 93.74 & 91.67 & 94.06 & 92.4 & 92.34 \\
Crude protein (\%) & 34.41 & 48.17 & 12.38 & 10.15 & 59.51 \\
Crude fat (\%) & 4.28 & 7.12 & 13.46 & 2.3 & 4.58 \\
Crude fiber (\%) & 2.03 & 1.12 & 12.74 & 2.67 & 1.23 \\
Ash (\%) & 9.63 & 24.66 & 10.17 & 2.06 & 1.36 \\
Gross energy (kcal g-1) & 4.17 & 2.65 & 3.18 & 2.95 & 4.35 \\
Carbohydrates (NFE) & 45.48 & 16.28 & 48.07 & 79.87 & 28.97 \\
\hline
\end{tabular}

(AOAC, 1995). $\mathrm{Cr}_{2} \mathrm{O}_{3}$ was used as inert marker at the rate of $1 \%$ in all the test diets. All feed ingredients were thoroughly mixed in a feed mixer for about 5-10 min. Feed ingredients were blended slowly into the mixer after adding $10-15 \%$ of tap water to form suitably textured dough which was pelleted using a pelleting machine (Lovell, 1989). Five phytase supplemented test diets were prepared by spraying graded levels $(300,600$, 900, 1200 and $1500 \mathrm{FTU} \mathrm{kg}^{-1}$ ) of phytase. The required concentrations of phytase enzyme (Phyzyme ${ }^{\circledR}$ XP 10000 FTU g ${ }^{-1}$; Danisco Animal Nutrition, Fin-65101 Vaasa, Finland) were prepared in $25 \mathrm{ml}$ distilled water and sprayed on $1 \mathrm{~kg}$ of each test diet (Robinson et al., 2002). Control diet ( 0 FTU kg-1 level) was sprayed with an equal amount of distilled water to maintain equivalent level of moisture. All the diets prepared were dried and stored at $4^{\circ} \mathrm{C}$ until use.

\section{Feeding protocol and sample collection}

C. catla fingerlings were fed at the rate of $4 \%$ of live wet body weight on respective diet, twice daily. After the feeding session of $2 \mathrm{~h}$, the uneaten diet was drained out from each tank by opening the valves of the tanks. The tanks were washed completely to remove the feed particles and refilled with tap water. Fecal material was collected carefully to avoid the breakage of faeces for minimising the leaching of nutrients in water. Faeces were dried in oven at $65^{\circ} \mathrm{C}$ and stored for further chemical analysis.

\section{Chemical analysis of feed and faeces}

Moisture content of test diets and faeces were calculated after oven drying of homogenised samples at $105^{\circ} \mathrm{C}$ for $12 \mathrm{~h}$. Micro Kjeldahl Apparatus (InKjel M behr Labor Technik GmbH D-40599 Dusseldorf) was used to determine the crude protein $(\mathrm{CP})$ content $(\mathrm{N} \times 6.25)$. Soxhlet system (Soxhlet Extraction Heating Mantels, $250 \mathrm{ml} \mathrm{53868601)}$ was used to analyse the crude fat (EE). Crude fiber content was estimated by digestion with $1.25 \% \mathrm{H}_{2} \mathrm{SO}_{4}$ and $1.25 \% \mathrm{NaOH}$. The difference in weight after calcination indicates the quantity of fibre present. Ash was determined by ignition at $650^{\circ} \mathrm{C}$ for $12 \mathrm{~h}$ in electric furnace (Naberthern B170) to constant weight.
Total carbohydrates ( $\mathrm{N}$-free extract) were calculated using standard formula:

Total carbohydrates $(\%)=100-(\mathrm{EE} \%+\mathrm{CP} \%+\mathrm{Ash} \%+\mathrm{CF} \%)$.

Oxygen bomb calorimeter was used to estimate the gross energy (GE) of samples. Chromic oxide contents in the diets and faeces were estimated after oxidation with molybdate reagent using a UV-VIS 2001 Spectrophotometer at $370 \mathrm{~nm}$ (Divakaran et al., 2002).

Apparent nutrient digestibility coefficient (ADC) of test diets was calculated using the standard formula (NRC, 1993):

$$
\text { ADC }(\%)=100-100 \times \frac{\% \text { Marker in diet } \times \% \text { Nutrient in faeces }}{\% \text { Marker in faeces } \times \% \text { Nutrient in diet }}
$$

\section{Evaluation of growth}

The fish were bulk weighed in each tank at start and at end of the study period to evaluate the growth performance of $C$. catla fingerlings. Growth parameters such as weight gain (g), FCR, specific growth rate (SGR) and weight gain \% of fingerlings were calculated using standard formulae (NRC, 1993):

$$
\begin{aligned}
& \text { Weight gain }(\%)=\frac{(\text { Final weight }- \text { Initial weight }) \times 100}{\text { Initial weight }} \\
& \text { FCR } \\
& =\frac{\text { Total dry feed intake }(\mathrm{g})}{\text { Wet weight gain }(\mathrm{g})} \\
& \text { SGR }(\%) \quad=\frac{(\text { ln. final wt. of fish }- \text { ln. initial wt. of fish }) \times 100}{\text { Trial day }}
\end{aligned}
$$

\section{Hematological study}

Blood samples were collected from the caudal vein using heparinised syringe and were analysed for hematological indices at Molcare Lab, Department of Biochemistry, University of Agriculture, Faisalabad, Pakistan. Micro-hematocrit technique was used to determine hematocrit/packed cell volume (PCV) value as per Brown (1980). Red blood cells (RBC) and white blood cells (WBC) counts were analysed using a Neubauer counting chamber (Blaxhall and Daisley, 1973). 
Hemoglobin $(\mathrm{Hb})$ concentration was determined as described by Wedemeyer and Yastuke (1977). Mean corpuscular hemoglobin concentration (MCHC); mean corpuscular hemoglobin $(\mathrm{MCH})$ and mean cell volume (MCV) were calculated using the following formulae:

$$
\begin{aligned}
& \mathrm{MCHC}=\mathrm{Hb} / \mathrm{PCV} \times 100 \\
& \mathrm{MCV}=\mathrm{PCV} / \mathrm{RBC} \times 10 \\
& \mathrm{MCH}=\mathrm{Hb} / \mathrm{RBC} \times 10
\end{aligned}
$$

\section{Statistical analysis}

Data of ADC of nutrients (CP, EE and GE), growth parameters as well as haematological indices were subjected to one way analysis of variance (Steel et al., 1996). The differences among treatments were compared by Tukey's Honesty Significant Difference Test and considered significant at $\mathrm{p}<0.05$ (Snedecor and Cochran, 1991). The CoStat Computer Package (Version 6.303, PMB 320, Monterey, CA, 93940 USA) was used for statistical analyses.

\section{Results}

Nutrient levels were approximately similar in control as well as all the phytase supplemented MOSM based test diets (Table 3).

Nutrients in faeces were significantly $(p<0.05)$ different between fish fed on control and phytase supplemented MOSM based test diets (Table 4). It was found that lower amount of nutrients was excreted through faeces of fingerlings fed on phytase supplemented MOSM based diets as compared to fishes fed on control diet. Lowest amount of nutrients was discharged through faeces when fingerlings were fed on diet supplemented with phytase at $900 \mathrm{FTU} \mathrm{kg}^{-1}$ followed by $600 \mathrm{FTU} \mathrm{kg}^{-1}$ level.

It was found that $900 \mathrm{FTU} \mathrm{kg}^{-1}$ level showed maximum digestibility values of crude fat i.e. $\mathrm{EE}(80 \%)$, crude protein i.e. $\mathrm{CP}(72 \%)$ and gross energy i.e. GE (74\%). These values were significantly $(p<0.05)$ different from control diet as well as remaining phytase supplemented test diets. Lowest ADC of nutrients (EE 49, CP 52 and GE 53\%) was observed when fish were fed on control diet ( 0 FTU kg-1 level) as compared to phytase supplemented MOSM based diets (Table 5). From these results it was also noted that increasing ADC of nutrients resulted in decreased nutrient discharge through faeces in water.

Results of fish growth parameters viz., weight gain, FCR and SGR are shown in Table 6. Phytase supplementation was found to significantly $(p<0.05)$ improve growth performance of $C$. catla fingerlings fed MOSM based diets as compared to control diet. Growth parameters of $C$. catla fingerlings was found to increase from $300 \mathrm{FTU} \mathrm{kg}^{-1}$ level and reached maximum at $900 \mathrm{FTU} \mathrm{kg}^{-1}$ level of phytase supplementation.

Maximum weight gain (20 g) and SGR (1.37) were observed in fingerlings fed phytase supplemented diet at $900 \mathrm{FTU} \mathrm{kg}^{-1}$ level followed by fish fed on test diet III supplemented with $600 \mathrm{FTU} \mathrm{kg}^{-1}$ level (weight gain $17 \mathrm{~g}$ and SGR 1.27). These values were significantly $(\mathrm{p}<0.05)$ higher as compared to weight gain $(13 \mathrm{~g})$ and SGR (1.04\%) of fish fed on control diet (without phytase).

Table 3. Apparent crude protein (CP), crude fat (EE) and gross energy (GE) levels in the experimental diets

\begin{tabular}{lllc}
\hline Experimental diets & Phytase levels $\left(\mathrm{FTU} \mathrm{kg}{ }^{-1}\right)$ & $\mathrm{CP}(\%)$ & EE $(\%)$ \\
\hline Test diet I (Control diet) & 0 & $32.99 \pm 0.17$ & $8.05 \pm 0.09$ \\
Test diet II & 300 & $32.89 \pm 0.17$ & $8.08 \pm 0.05$ \\
Test diet III & 600 & $33.20 \pm 0.36$ & $8.03 \pm 0.06$ \\
Test diet IV & 900 & $33.23 \pm 0.58$ & $8.03 \pm 0.09$ \\
Test diet V & 1200 & $32.84 \pm 0.53$ & $8.01 \pm 0.11$ \\
Test diet VI & 1500 & $33.59 \pm 0.35$ & $8.02 \pm 0.05$ \\
\hline
\end{tabular}

\begin{tabular}{|c|c|c|c|c|}
\hline Experimental diets & Phytase levels (FTU kg-1) & $\mathrm{CP}(\%)$ & $\mathrm{EE}(\%)$ & $\mathrm{GE}\left(\mathrm{kcal} \mathrm{g}^{-1}\right)$ \\
\hline Test diet I (Control diet) & 0 & $16.92 \pm 0.17^{\mathrm{e}}$ & $4.31 \pm 0.09^{\mathrm{e}}$ & $1.80 \pm 0.04^{\mathrm{e}}$ \\
\hline Test diet II & 300 & $14.06 \pm 0.10^{\mathrm{c}}$ & $3.75 \pm 0.05^{\mathrm{d}}$ & $1.61 \pm 0.07^{\mathrm{cd}}$ \\
\hline Test diet III & 600 & $12.10 \pm 0.36^{\mathrm{b}}$ & $2.44 \pm 0.12^{b}$ & $1.37 \pm 0.05^{\mathrm{b}}$ \\
\hline Test diet IV & 900 & $9.97 \pm 0.06^{\mathrm{a}}$ & $1.69 \pm 0.12^{\mathrm{a}}$ & $0.99 \pm 0.05^{\mathrm{a}}$ \\
\hline Test diet V & 1200 & $14.92 \pm 0.18^{\mathrm{d}}$ & $3.16 \pm 0.16^{\mathrm{c}}$ & $1.54 \pm 0.07^{\mathrm{c}}$ \\
\hline Test diet VI & 1500 & $14.24 \pm 0.27^{\mathrm{c}}$ & $3.86 \pm 0.07^{\mathrm{d}}$ & $1.6 \pm 0.08^{\mathrm{de}}$ \\
\hline
\end{tabular}

Values are Mean \pm SD

Table 4. Composition (\%) of apparent CP, EE and GE in faeces of C. catla fingerlings fed on experimental diets

Values are Mean \pm SD

Means within same columns having different superscripts are significantly different $(\mathrm{p}<0.05)$ 
Minimum FCR (1.15) of fingerlings was found at 900 FTU $\mathrm{kg}^{-1}$ followed by $600 \mathrm{FTU} \mathrm{kg}^{-1}$ (1.26). It was noted that FCR values at these levels were significantly $(\mathrm{p}<0.05)$ different from that of control diet and remaining levels of phytase supplemented diets (Table 7). Highest (1.60) FCR was observed in fish fed on control diet $\left(0 \mathrm{FTU} \mathrm{kg}{ }^{-1}\right.$ level).

Phytase supplementation played a significant $(\mathrm{p}<0.05)$ role in improving hematological indices of
C. catla fingerlings as compared to the fish fed on control diet (0 FTU $\mathrm{kg}^{-1}$ level). Maximum values of WBCs $\left(7.91 \times 10^{3} \mathrm{~mm}^{-3}\right)$, RBCs $\left(3.02 \times 10^{6} \mathrm{~mm}^{-3}\right)$ and $\mathrm{Hb}\left(9.03 \mathrm{~g} 100 \mathrm{ml}^{-1}\right)$ were noted in fish fed MOSM based diet supplemented with $900 \mathrm{FTU} \mathrm{kg}^{-1}$ level of phytase and were statistically $(\mathrm{p}<0.05)$ similar with the fish fed at $600 \mathrm{FTU} \mathrm{\textrm {kg } ^ { - 1 }}$ level. On the other hand, minimum values of WBCs $\left(7.11 \times 10^{3} \mathrm{~mm}^{-3}\right)$, RBCs

Table 5. Apparent nutrient digestibility (\%) of MOSM based diets fed to C. catla fingerlings

\begin{tabular}{lllll}
\hline Experimental diets & Phytase levels $\left(\mathrm{FTU} \mathrm{kg}^{-1}\right)$ & CP $(\%)$ & EE $(\%)$ & GE $(\%)$ \\
\hline Test diet I (Control diet) & 0 & $51.62 \pm 0.29^{\mathrm{e}}$ & $49.47 \pm 0.91^{\mathrm{e}}$ & $52.62 \pm 0.61^{\mathrm{d}}$ \\
Test diet II & 300 & $60.002 \pm 0.32^{\mathrm{c}}$ & $56.54 \pm 0.71^{\mathrm{d}}$ & $58.46 \pm 0.87^{\mathrm{c}}$ \\
Test diet III & 600 & $66.01 \pm 0.48^{\mathrm{b}}$ & $71.63 \pm 0.99^{\mathrm{b}}$ & $64.71 \pm 0.99^{\mathrm{b}}$ \\
Test diet IV & 900 & $72.23 \pm 0.58^{\mathrm{a}}$ & $80.45 \pm 0.80^{\mathrm{a}}$ & $74.44 \pm 0.81^{\mathrm{a}}$ \\
Test diet V & 1200 & $56.31 \pm 0.47^{\mathrm{d}}$ & $62.61 \pm 0.77^{\mathrm{c}}$ & $59.32 \pm 0.78^{\mathrm{c}}$ \\
Test diet VI & 1500 & $60.13 \pm 0.17^{\mathrm{c}}$ & $54.86 \pm 0.83^{\mathrm{d}}$ & $53.68 \pm 0.89^{\mathrm{d}}$ \\
\hline
\end{tabular}

Values are Mean \pm SD

Means within same columns having different superscripts are significantly different $(\mathrm{p}<0.05)$

Table 6. Growth performance of $C$. catla fingerlings fed graded levels of phytase supplemented MOSM based diets

\begin{tabular}{|c|c|c|c|c|c|c|}
\hline \multirow{3}{*}{ Growth parameters } & Test diet I (Control diet) & Test diet II & Test diet III & Test diet IV & Test diet V & Test diet VI \\
\hline & \multicolumn{6}{|c|}{ Phytase levels (FTU kg ${ }^{-1}$ ) } \\
\hline & 0 & 300 & 600 & 900 & 1200 & 1500 \\
\hline IW (g) & $8.04 \pm 0.015$ & $8.04 \pm 0.015$ & $8.037 \pm 0.02$ & $8.07 \pm 0.04$ & $8.06 \pm 0.02$ & $8.15 \pm 0.03$ \\
\hline $\mathrm{FW}(\mathrm{g})$ & $20.56 \pm 0.09^{\mathrm{e}}$ & $22.02 \pm 0.11^{\mathrm{d}}$ & $25.24 \pm 0.16^{\mathrm{b}}$ & $27.81 \pm 0.18^{\mathrm{a}}$ & $23.49 \pm 0.22^{\mathrm{c}}$ & $22.58 \pm 0.18^{\mathrm{d}}$ \\
\hline WG (g) & $12.52 \pm 0.08^{\mathrm{e}}$ & $13.98 \pm .01^{\mathrm{d}}$ & $17.20 \pm 0.17^{b}$ & $19.74 \pm 0.14^{\mathrm{a}}$ & $15.43 \pm 0.21^{\mathrm{c}}$ & $14.43 \pm 0.2^{\mathrm{d}}$ \\
\hline WG $(\%)$ & $155.66 \pm 0.91^{\mathrm{e}}$ & $173.77 \pm 1.29^{\mathrm{d}}$ & $214.06 \pm 2.22^{\mathrm{b}}$ & $244.57 \pm 1.37^{\mathrm{a}}$ & $191.32 \pm 2.60^{\mathrm{c}}$ & $171.17 \pm 2.32^{\mathrm{d}}$ \\
\hline WG $\left(\right.$ fish $^{-1}$ day $\left.^{-1}\right)(\mathrm{g})$ & $0.14 \pm 0.001^{\mathrm{e}}$ & $0.16 \pm 0.001^{\mathrm{d}}$ & $0.19 \pm 0.002^{\mathrm{b}}$ & $0.22 \pm 0.002^{\mathrm{a}}$ & $0.17 \pm 0.002^{\mathrm{c}}$ & $0.16 \pm 0.002^{\mathrm{d}}$ \\
\hline FI & $0.22 \pm 0.002^{\mathrm{d}}$ & $0.23 \pm 0.002^{\mathrm{c}}$ & $0.24 \pm 0.003^{b}$ & $0.25 \pm 0.002^{\mathrm{a}}$ & $0.23 \pm 0.002^{\mathrm{c}}$ & $0.23 \pm 0.002^{\text {cd }}$ \\
\hline FCR & $1.60 \pm 0.005^{\mathrm{f}}$ & $1.49 \pm 0.004^{\mathrm{e}}$ & $1.26 \pm 0.004^{b}$ & $1.15 \pm 0.002^{\mathrm{a}}$ & $1.36 \pm 0.01^{\mathrm{c}}$ & $1.42 \pm 0.02^{\mathrm{d}}$ \\
\hline SGR & $1.04 \pm 0.004^{\mathrm{e}}$ & $1.12 \pm 0.01^{\mathrm{d}}$ & $1.27 \pm 0.01^{\mathrm{b}}$ & $1.37 \pm 0.004^{\mathrm{a}}$ & $1.19 \pm 0.01^{\mathrm{c}}$ & $1.13 \pm 0.01^{\mathrm{d}}$ \\
\hline
\end{tabular}

Values are $\mathrm{Mean} \pm \mathrm{SD}(\mathrm{n}=3)$

Means within same columns having different superscripts are significantly different $(\mathrm{p}<0.05)$

$\mathrm{IW}=$ Initial weight, $\mathrm{FW}=$ Final weight, $\mathrm{WG}=$ Weight gain, $\mathrm{FI}=$ Feed intake, $\mathrm{SGR}=$ Specific growth rate, $\mathrm{FCR}=\mathrm{Feed}$ conversion ratio

Table 7. Hematological parameters of $C$. catla fingerlings fed MOSM based control and phytase supplemented test diets

\begin{tabular}{|c|c|c|c|c|c|c|}
\hline \multirow{3}{*}{ Hematological indices } & Test diet I (Control diet) & Test diet II & Test diet III & Test diet IV & Test diet V & Test diet VI \\
\hline & \multicolumn{6}{|c|}{ Phytase levels (FTU kg-1) } \\
\hline & 0 & 300 & 600 & 900 & 1200 & 1500 \\
\hline WBC $\left(10^{3} \mathrm{~mm}^{-3}\right)$ & $7.11 \pm 0.08^{c}$ & $7.30 \pm 0.07^{\mathrm{b}}$ & $7.77 \pm 0.06^{\mathrm{a}}$ & $7.91 \pm 0.08^{\mathrm{a}}$ & $7.49 \pm 0.06^{\mathrm{b}}$ & $7.34 \pm 0.06^{\mathrm{b}}$ \\
\hline $\operatorname{RBC}\left(10^{6} \mathrm{~mm}^{-3}\right)$ & $1.47 \pm 0.07^{\mathrm{d}}$ & $1.80 \pm 0.06^{\mathrm{c}}$ & $2.83 \pm 0.05^{\mathrm{a}}$ & $3.02 \pm 0.05^{\mathrm{a}}$ & $2.33 \pm 0.09^{\mathrm{b}}$ & $1.82 \pm 0.14^{\mathrm{c}}$ \\
\hline $\mathrm{Hb}\left(\mathrm{g} 100 \mathrm{ml}^{-1}\right)$ & $7.11 \pm 0.09^{\mathrm{e}}$ & $7.43 \pm 0.10 \mathrm{~d}^{\mathrm{e}}$ & $8.66 \pm 0.06^{b}$ & $9.03 \pm 0.12^{\mathrm{a}}$ & $8.00 \pm 0.21^{\mathrm{c}}$ & $7.51 \pm 0.09^{\mathrm{d}}$ \\
\hline $\operatorname{PCV}(\%)$ & $21.23 \pm 0.27^{\mathrm{e}}$ & $22.02 \pm 0.16^{\mathrm{d}}$ & $23.83 \pm 0.09^{\mathrm{c}}$ & $26.02 \pm 0.18^{\mathrm{b}}$ & $29.04 \pm 0.36^{\mathrm{a}}$ & $24.07 \pm 0.17^{\mathrm{c}}$ \\
\hline PLT & $55.89 \pm 0.54^{\mathrm{d}}$ & $61.39 \pm 0.42^{\mathrm{c}}$ & $62.32 \pm 0.22^{\mathrm{c}}$ & $65.79 \pm 0.53^{\mathrm{b}}$ & $67.89 \pm 0.39^{\mathrm{a}}$ & $68.76 \pm 0.24^{\mathrm{a}}$ \\
\hline MCV (fl) & $104.32 \pm 0.96^{\mathrm{e}}$ & $91.19 \pm 0.27^{\mathrm{f}}$ & $182.67 \pm 0.26^{\mathrm{b}}$ & $158.58 \pm 0.35^{\mathrm{c}}$ & $127.63 \pm 0.28^{\mathrm{d}}$ & $201.43 \pm 0.29^{\mathrm{a}}$ \\
\hline $\mathrm{MCH}(\mathrm{pg})$ & $28.90 \pm 0.25^{\mathrm{e}}$ & $25.60 \pm 0.32^{\mathrm{f}}$ & $39.65 \pm 0.28^{c}$ & $46.85 \pm 0.36^{\mathrm{b}}$ & $35.65 \pm 0.09^{\mathrm{d}}$ & $59.90 \pm 0.21^{\mathrm{a}}$ \\
\hline $\mathrm{MCHC}(\%)$ & $25.58 \pm 0.53^{\mathrm{e}}$ & $27.74 \pm 0.24^{\mathrm{d}}$ & $33.84 \pm 0.12^{\mathrm{c}}$ & $35.25 \pm 0.30^{\mathrm{b}}$ & $28.53 \pm 0.31^{\mathrm{d}}$ & $37.31 \pm 0.29^{\mathrm{a}}$ \\
\hline
\end{tabular}

Values are Mean \pm SD ( $=3$ )

Means within rows having different superscripts are significantly different $(\mathrm{p}<0.05)$

$\mathrm{WBC}=$ White blood cells, $\mathrm{RBC}=$ Red blood cells, PCV $=$ Packed cell volume, $\mathrm{Hb}=$ hemoglobin concentration, $\mathrm{PLT}=\mathrm{Platelet}$, MCV $=$ Mean corpuscular volume, $\mathrm{fl}=$ Femtoliters, $\mathrm{MCH}=$ Mean corpuscular hemoglobin, $\mathrm{pg}=$ Pictograms, $\mathrm{MCHC}=$ Mean corpuscular hemoglobin concentration 


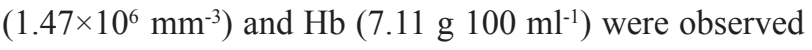
in fish fed on control diet without phytase supplementation. The highest PCV (29.04\%) and platelet (PLT, 63.95) values were noted in fish fed at $1200 \mathrm{FTU} \mathrm{kg}^{-1}$ diet followed by values of 26.02 and $65.79 \%$, respectively in fish fed on $900 \mathrm{FTU} \mathrm{kg}^{-1}$ level diet. MCH (59.90 pg) and MCHC $(37.31 \%)$ were highest in fish fed on diets supplemented with $1500 \mathrm{FTU} \mathrm{kg}^{-1}$ of phytase.

\section{Discussion}

According to the results of the current study, it was found that addition of phytase in MOSM based diets was useful for improvement in apparent digestibility coefficient (ADC) of nutrients in C. catla fingerlings. Highest values for $\mathrm{ADC} \%$ of $\mathrm{CP}(72 \%)$, $\mathrm{EE}(80 \%)$ and $\mathrm{GE}(74 \%)$ were found when fish were fed diet supplemented with phytase at $900 \mathrm{FTU} \mathrm{kg}^{-1}$ level. Similarly, Ashraf and Goda (2007) observed that optimal level of phytase enzyme for highest $\mathrm{CP}$ digestibility was $1000 \mathrm{FTU} \mathrm{kg}^{-1}$. They also found that $\mathrm{ADC} \%$ of $\mathrm{CP}$ could not be further improved on higher supplementation levels of this enzyme. Nearly similar to our results, Hussain et al. (2015a) found higher CP digestibility in $C$. mrigala fingerlings when fed soybean meal based test diet supplemented with phytase at 1000 FTU $\mathrm{kg}^{-1}$ level. Maximum CP digestibility was observed in L. rohita fingerlings fed phytase supplemented soybean meal based diet (Baruah et al., 2007a), cottonseed and sunflower meal based diets (Hussain et al., 2011; $2015 \mathrm{~b}$ ) at $750 \mathrm{FTU} \mathrm{kg}^{-1}$ level. In contrast, non-significant $(p<0.05)$ values of protein digestibility were reported after phytase supplementation in plant meal based diets (Cheng and Hardy, 2002; Yan and Reigh, 2002; Dalsgaard et al., 2009). In another study, decreased CP digestibility was found in Psetta maxima (turbot) fed phytase supplemented rapeseed protein concentrate as compared to control diet (Danwitz et al., 2016). Similar to present findings, Hussain et al. (2014) found maximum EE and GE digestibility at $1000 \mathrm{FTU} \mathrm{kg}^{-1}$ level when $C$. mrigala fingerlings were fed soybean meal based diet. On the other hand, 750 FTU kg-1 level was suggested as the most suitable level of supplementation for higher fat digestibility in L. rohita fingerlings (Baruah et al., 2007b). Higher EE digestibility was found in Nile tilapia when fed on 1000 and $2000 \mathrm{FTU} \mathrm{kg}^{-1}$ of phytase supplemented diets (Portz and Liebert, 2004). Hydrolysis of chelated phytic acid resulted in lower EE excretion in faeces that ultimately showed higher utilisation of $\mathrm{EE}$ by fish fingerlings resulting in higher digestibility (Hussain et al., 2014; 2015a,b). In contrary, Dalsgaard et al. (2009) observed nonsignificant $(\mathrm{p}<0.05)$ results of fat digestibility in Oncorhynchus mykiss fed phytase supplemented soybean meal based diets. However, decreased EE digestibility was found in O. mykiss fed phytase supplemented soybean meal based diet. The probable reason for this reduction in fat digestibility might be that the phytase supplementation inhibited lipase activity which led to decreased lipase hydrolysis efficiency for lipids, resulting in reduced lipid digestibility (Wang et al., 2009).

Many researchers observed increased GE digestibility values for L. rohita (Hussain et al., 2015a; 2016), C. mrigala (Hussain et al., 2014), O. mykiss (Forster et al., 1999) and Nile tilapia (Ashraf and Goda, 2007) when fish were fed with phytase supplemented plant protein based diet. Hussain et al. (2011) observed maximum GE digestibility in L. rohita fingerlings when fish were fed phytase supplemented canola meal based diet at 750 FTU kg-1 level. According to another similar study, highest ADC of GE was recorded at 1000 FTUkg $^{-1}$ level which decreased on further increase (1500 FTU kg ${ }^{-1}$ ) in phytase supplementation (Ashraf and Goda, 2007). However, Lanari et al. (1998) noted that there was no optimistic response in rainbow trout fed phytase supplemented soybean meal based diets. They argued that it was due to various nutritional factors, source or type of phytase enzyme as well as source and amount of phytic acid (Selle et al., 2000).

Presence of phytate in feed reduces fish growth performance in terms of weight gain, FCR and SGR (Spinelli et al., 1983). Maximum growth was observed in fish fed on $900 \mathrm{FTU} \mathrm{kg}^{-1}$ level of phytase in MOSM based diet. Nearly similar results were found when common carp fingerlings were fed with $800 \mathrm{FTU} \mathrm{kg}^{-1}$ supplementation in plant-meal based diet (Bai et al., 2003). Nwanna et al. (2007) also found a significant $(\mathrm{p}<0.05)$ increase in overall $\mathrm{WG}$ and $\mathrm{WG} \%$ in $C$. carpio when fed with diets supplemented with phytase at 750 and 1000 FTU $\mathrm{kg}^{-1}$ levels. In another study, positive results were found by Hussain et al. (2015b), but on a slightly different (750 FTU $\mathrm{kg}^{-1}$ ) level of phytase supplementation. In contrast, non-significant $(\mathrm{p}<0.05)$ effect of phytase supplementation was reported in case of $O$. mykiss when fingerlings were fed phytase supplemented plant meal based diets (Vielma et al., 2000). Similarly, in contradiction to the present findings, many other researchers did not observe any significant $(p<0.05)$ effect of phytase supplementation on fish growth performance, when these fish species were fed with or without phytase supplemented plant meal based diets (Robinson et al., 2002, Baruah et al., 2007a, Lim and Lee, 2009, Wang et al., 2009). This disparity in results for growth indices may be linked with many factors such as types of feed ingredients used, varying levels of phytase, processing methods of feed, fish species, stomach $\mathrm{pH}$ and methods used for feed drying (Wang et al., 2009). 
Current study showed lowest FCR value (1.15) and maximum SGR (1.37) in C. catla fingerlings fed on $900 \mathrm{FTU} \mathrm{kg}^{-1}$ phytase supplemented diet. Similar to our results, Riche and Garling (2004); Ashraf and Goda (2007) and Cao et al. (2008) observed maximum SGR and lowest FCR values when $O$. niloticus were fed plant meal based diets supplemented with phytase at $1000 \mathrm{FTU} \mathrm{kg}^{-1}$ level. On the other hand, maximum SGR in O. mykiss was observed when they were fed on phytase supplemented plant based diets at $500 \mathrm{FTU} \mathrm{kg}^{-1}$ level (Forster et al., 1999). In contrast to current findings, higher FCR values for stripped seabass Morone saxatilis were observed when fed with a higher dose (1300 FTU $\mathrm{kg}^{-1}$ ) of phytase in plant meal based diet (Hughes and Soares, 1998). Statistically non-significant $(\mathrm{p}>0.05)$ difference was observed in terms of growth performance when parrot fish were fed on different plant meal based diets supplemented with phytase at different levels (Lim and Lee, 2009). Activity of phytase supplementation depends on the quantity of phytate present in plant meal based diets, environmental conditions, experimental fish species and source of phytase enzyme (Kumar et al., 2011).

Toxic constituents present in fish feed can affect the blood formation. Hematological parameters provide important information in monitoring stress response of fish and in the improvement of fish health (Hrubec et al., 2000). As phytate chelates with iron, that is essential for formation of RBCs, it can lead to lowered oxygen carrying capacity of blood (Spinelli et al., 1983). In the present study, maximum values of WBCs, RBCs and $\mathrm{Hb}$ were found at $900 \mathrm{FTU} \mathrm{kg}^{-1}$ level phytase supplemented MOSM based diet. Phytase supplementation is suggested as a powerful stimulator of immune system in fish, resulting in higher number of monocytes (macrophages) and higher blood cell production in monogastric animals (Ehsani and Torki, 2010). In contrary to present findings, Baruah et al. (2009) found non-significant ( $>>0.05)$ effects on RBCs, WBCs hematocrit and hemoglobin in L. rohita fingerlings fed phytase supplemented (500 FTU $\mathrm{kg}^{-1}$ level) soybean meal based diet. They argued that fish were fed a diet containing both phytase and citric acid, which would have led to release of higher amount of $\mathrm{Cu}$ and $\mathrm{Fe}$ from chelated phytate which resulted in improving hematological para,eters of fish. Similarly, the values of $\mathrm{RBCs}, \mathrm{WBCs}$ and $\mathrm{Hb}$ were found higher in Cyprinus carpio fed diets supplemeted at $500 \mathrm{FTU} \mathrm{kg}^{-1}$ level of phytase in soya protein based diet (Sardar et al., 2007). Encouraging results were found when phytase was used in Gadus morhua (Atlantic cod) feed which resulted in higher number of WBCs as compared to fish fed control diet (Lazado et al., 2010). Hemoglobin (Hb) level in fish fed phytase supplemented diet was slightly higher than that of fish fed a diet without phytase, but was not significantly $(\mathrm{p}<0.05)$ different from that of other dietary treatments (Yoo and Bai, 2014).

Supplementation of phytase played a major role in improving $\mathrm{ADC}$ of nutrients, growth performance and hematological indices of $C$. catla fingerlings as compared to control diet in the present study. Furthermore, it was also found that $900 \mathrm{FTU} \mathrm{kg}^{-1}$ is the optimum level of phytase supplementation in MOSM based diet for the maximum improvement in fish performance.

\section{References}

Abdulkadir, A. R., Zawawi, D. D. and Jahan, M. S. 2016. Proximate and phytochemical screening of different parts of Moringa oleifera. Russian Agri. Sci., 42: 34-36.

Allan, G. L. and Rowland, S. J. 1992. Development of an experimental diet for silver perch (Bidynus bidyanus). Austasia Aqua., 6: 39-40.

Alvi, A. S. 1994. Adventitious toxins in plant origin feedstuffs: Quantification and tolerance level in fish. Masters dissertation, Aligarh Muslim University, Aligarh, India.

AOAC 1995. Official methods of analysis, $15^{\text {th }}$ edn. Association of Official Analytical Chemists, Washington, D.C., USA., p. 1094.

Ashraf, M. and Goda, A. S. 2007. Effect of dietary soybean meal and phytase levels on growth, feed utilisation and phosphorus discharge for Nile tilapia (Oreochromis niloticus L.). J. Fish. Aquatic Sci., 2: 248-263.

Aslam, S., Abbas, S., Kalhoro, M. A. and Shoaib, A. 2016. Anchor worms (lernaeid parasites), Lernaea polymorpha Yyu and Lernaea cyprinacea (copepode: lernaeidae) on major carps at different fish farms in Punjab, Pakistan. Sci. Int., 28: 295-298.

Bai, D. Q., Qiao, X. T., Wei, D., Guo, L. and Qi, H. L. 2003. Effects of phytase on utilisation ratio of nutrient composition (calcium, phosphorus.) of Carp (Cyprinus carpio L.). J. Tianjin Agric. Coll., 10: 6-11 [in Chinese].

Baruah, K., Pal, A. K., Sahu, N. P., Debnath, D., Yengkokpam, S., Norouzitallab, P. and Sorgeloos, P. 2009. Dietary crude protein, citric acid and microbial phytase interacts to influence the hemato-immunological parameters of rohu, Labeo rohita juveniles. J. World Aquac. Soc., 40: 824-831.

Baruah, K., Pal, A. K., Narottam, P. S. and Debnath, D. 2007a. Microbial phytase supplementation in rohu, Labeo rohita, diets enhances growth performance and nutrient digestibility. J. World Aquac. Soc., 38: 129-137.

Baruah, K., Sahu, P. N., Pal, A. K., Jain, K. K., Debnath, D. and Mukherjee, C. S. 2007b. Dietary microbial phytase and 
citric acid synergistically enhances nutrient digestibility and growth performance of Labeo rohita (Hamilton) juveniles at sub-optimal protein level. Aquac. Res., 38: 109-120.

Blaxhall, P. C. and Daisley, K. W. 1973. Routine haematological methods for use with fish blood. J. Fish Biol., 6: 771-781.

Brown, B. A. 1980. Routine hematology procedures. Hematology: Principles and procedures, p. 71-112.

Cao, L., Wang, W., Yang, C., Yang, Y., Diana, J., Yakupitiyage, A., Luo, Z. and Li, D. 2007. Application of microbial phytase in fish feed. J. Enzyme Microb. Tech., 40: 497-507.

Cao, L., Yang, Y., Wang, W. M., Yakupitiyage, A., Yuan, D. R. and Diana, J. S. 2008. Effect of pre-treatment with microbial phytase on phosphorus utilisation and growth performance of Nile tilapia (Oreochromis niloticus). Aquac. Nutr., 14: 99-109.

Cheng, Z. J. and Hardy, R. W. 2002. Effect of microbial phytase on apparent nutrient digestibility of barley, canola meal, wheat and wheat middlings, measured in vivo using rainbow trout (Oncorhynchus mykiss). Aquac. Nutr., 8: $271-277$.

Dalsgaard, J., Ekmann, K. S., Pedersen, P. B. and Verlhac, V. 2009. Effect of supplemented fungal phytase on performance and phosphorus availability by phosphorus depleted juvenile rainbow trout (Oncorhynchus mykiss) and on the magnitude and composition of phosphorus waste output. Aquaculture, 286: 105-112.

Danwitz, A. V., Bussel, C. G. J. V., Klatt, S. F. and Schulz, C. 2016. Dietary phytase supplementation in rapeseed protein based diets influences growth performance, digestibility and nutrient utilisation in turbot (Psetta maxima). Aquaculture, 450: 405-411.

Dawood, M. A. O., Koshio, S., Ishikawa, M. and Yokoyama, S. 2015. Effects of partial substitution of fish meal by soybean meal with or without heat-killed Lactobacillus plantarum (LP20) on growth performance, digestibility and immune response of Amberjack, Seriola dumerili juveniles. BioMed Res. Inter., Article ID 514196. http://dx.doi.org/10.1155/2015/514196

Divakaran, S., Leonard, G. O. and Lan, P. F. 2002. Note on the methods for determination of chromic oxide in shrimp feeds. J. Agric. Food Chem., 50: 464-467.

Ehsani, M. and Torki, M. 2010. Effects of dietary inclusion of guar meal supplemented by $\beta$-mannanase on performance of laying hens, egg quality characteristics and diacritical counts of white blood cells. American J. Anim. Vet. Sci., 5: $237-243$.

FAO 2015 Catla catla (Hamilton, 1822) Cultured Aquatic Species Information Programme, Fisheries and Aquaculture Department, Food and Agriculture Organisation, Rome.
Forster, I., Higgs, D. A., Dosanjh, B. S. and Rowshandeli, M. 1999. Potential for dietary phytase to improve the nutritive value of canola protein concentrate and decrease phosphorus output in rainbow trout (Oncorhynchus mykiss) held in $11^{\circ} \mathrm{C}$ freshwater. Aquaculture, 179: 109-125.

Hardy, R. W. 2010. Utilisation of plant proteins in fish diets: effects of global demand and supplies of fishmeal. J. Aquac. Res., 41: 770-776.

Hrubec, T. C., Cardinale, J. L. and Smith, S. A. 2000. Haematology and plasma chemistry reference intervals for cultured tilapia (O. niloticus). Vet. Clin. Path., 29: 7-12.

Hughes, K. P. and Soares, J. H. 1998. Efficacy of phytase on phosphorus utilisation in practical diets fed to striped bass, Morone saxatilis. Aquac. Nutr., 4: 133-140.

Hussain, S. M., Afzal, M., Javid, A., Hussain, A. I., Ali, Q., Mustafa, I., Chatha S. A. S., Shah S. Z. H., Hussain, M. and Ullah, M. I. 2015b. Efficacy of phytase supplementation on growth performance and mineral digestibility of Labeo rohita fingerlings fed on cottonseed meal based diet. Pakistan J. Zool., 47: 699-709.

Hussain, S. M., Afzal, M., Nasir, S., Javid, A., Azmat, H., Makhdoom, S. M. and Iqbal, M. 2016. Role of phytase supplementation in improving nutrient digestibility and growth performance for Labeo rohita fingerlings fed on canola meal-based diet. J. Appl. Anim. Res., p. 1-7.

Hussain, S. M., Afzal, M., Rana, S. A., Javed, A. and Iqbal, M. 2011. Effect of phytase supplementation on growth performance and nutrient digestibility of Labeo rohita fingerlings fed on corn gluten meal-based diets. Int. J. Agric. Biol., 13: 916-922.

Hussain, S. M., Shahzad, M. M., Afzal, M., Javid, A., Mubarik, M. S., Shah, S. Z. H., Hussain, M., Ahmad, S., Arsalan, M. Z. H., Manzoor, R. and Riaz, D. 2015a. Efficacy of phytase enzyme for increasing mineral digestibility of Cirrhinus mrigala fingerlings fed on soybean meal-based diet. Pakistan J. Zool., 47: 1807-1816.

Hussain, S. M., Shahzad, M. M., Jabeen, F., Nasir, S., Afzal, M., Javid, A., Ahmad, S., Arsalan, M. Z. H., Riaz, D., Khichi, T. A. A., Ahmad, A. W. and Furqan, M. 2014. Growth performance and nutrient digestibility of Cirrhinus mrigala fingerlings fed on soybean meal-based diet supplemented by phytase. Int. J. Biosc., 5: 212-221.

Kumar, V., Sinha, A. K., Makkar, H. P. S., De-Boeck, G. and Becker, K. 2011. Phytate and phytase in fish nutrition. J. Anim. Physiol. Anim. Nutr., 96: 335-364.

Lanari, D., Agaro, E. D. and Turri, C. 1998. Use of non-linear regression to evaluate the effects of phytase enzyme treatment of plant protein diets for rainbow trout (Oncorhynchus mykiss). Aquaculture, 161: 345-356. 
Lazado, C. C., Caipang, C. M. A., Gallage, S., Brinchmann, M. F. and Kiron, V. 2010. Responses of Atlantic cod Gadus morhua head kidney leukocytes to phytase produced by gastrointestinal-derived bacteria. Fish Physiol. Biochem., 36: 883-891.

Lim, S. J. and Lee, K. J. 2009. Partial replacement of fish meal by cottonseed meal and soybean meal with iron and phytase supplementation for parrot fish Oplegnathus fasciatus. Aquaculture, 290: 283-289.

Lim, S. J., Kim, S., Ko, G., Song, J., Oh, D., Kim, J. and Lee, K. 2011. Fish meal replacement by soybean meal in diets for tiger puffer, Takifu gurubripes. Aquaculture, 313: 165-170.

Liu, H., Jin, J., Zhu, X., Han, D., Yang, Y. and Xie, S. 2017. Effect of substitution of dietary fish meal by soybean meal on different sizes of gibel carp (Carassius auratus gibelio): digestive enzyme gene expressions and activities and intestinal and hepatic histology, Aquac. Nutr., 23: 129-147.

Liu, L. W., Su, J. M., Zhang, T., Liang X. Z. and Luo, Y. L. 2013. Apparent digestibility of nutrients in grass carp diet supplemented with graded levels of phytase using pre-treatment and spraying methods. Aquac. Nutr., 19: 91-99.

Lovell, R. T. 1989. Nutrition and feeding of fish. Van NostrandReinhold, New York, 260 pp.

Makkar, H. P. S. and Becker, K. 1996. Nutritional value and antinutritional components of whole and ethanol extracted Moringa oleifera leaves. Anim. Sci. Tech., 63: 211-228.

NRC 1993. Nutrient requirements of fish, National Research Council, National Academy Press, Washington, DC USA.

Nwanna, L. C., Eisenreich, R. and Schwarz, F. J. 2007. Effect of wet-incubation of dietary plant feedstuffs with phytases on growth and mineral digestibility by common carp Cyprinus carpio L. Aquaculture, 271: 461-468.

Portz, L. and Liebert, F. 2004. Growth, nutrient utilisation and parameters of mineral metabolism in Nile tilapia Oreochromis niloticus (Linnaeus, 1758) fed plant based diets with graded levels of microbial phytase. J. Anim. Physiol. Anim. Nutr., 88: 311-320.

Riche, M. and Garling, D. L. 2004. Effect of phytic acid on growth and nitrogen retention in tilapia Oreochromis niloticus L. Aquac. Nutr., 10: 389-400.

Robinson, E. H., Li, M. H. and Manning, B. B. 2002. Comparison of microbial phytase and dicalciumphosphate or growth and bone mineralisation of pond raised channel catfish, Ictalurus punctatus. J. Appl. Aquac., 12: 81-88.

Rowland, S. J. and Ingram, B. A. 1991. Diseases of Australian native fishes. Fisheries Bulletin 4, NSW Fisheries, Sydney, NSW, Australia.

Salem, H. B. and Makkar, H. P. S. 2009. Defatted Moringa oleifera seed meal as a feed additive for sheep. Anim. Feed Sci. Tech., 150: 27-33.
Sardar, P., Randhawa, H. S., Abid, M. and Prabhakar, S. K. 2007. Effect of dietry microbial phytase supplementation on growth performance, nutrient utilisation, body compositions and haemato-biochemical profiles of Cyprinus carpio (L.) fingerlings fed soyprotein-based diet. Aquac. Nutr., 13: 444-456.

Selle, P. H., Ravindran, V., Caldwell, A. and Bryden, W. L. 2000 Phytate and phytase: consequences for protein utilisation. Nutr. Res. Rev., 13: 255-278.

Snedecor, G. W. and Cochran, W. G. 1991. Statistical methods. $8^{\text {th }}$ edn. Iowa State University. Press, Ames., USA, 503 pp.

Spinelli, J., Houle, C. R. and Wekell, J. C. 1983. The effects of phytates on the growth of rainbow trout (Salmo gairdneri) fed purified diets containing varying quantities of calcium and magnesium. Aquaculture, 30: 71-83.

Steel, R. G. D., Torrie, J. H. and Dickey, D. A. 1996. Principles and procedures of statistics, $3^{\text {rd }}$ edn. McGraw Hill International Book Co., Inc., New York, USA, p. 336-352.

Tiamiyu, L. O., Okomoda, V. T. and Aende, A. 2016. Growth performance of Oreochromis niloticus fingerlings fed Moringa oleifera leaf as replacement for soybean meal. J. Aquac. Engin. Fish. Res., 2: 61-66.

Usmani, N. and Jafri, A. K. 2002. Influence of dietry phytic acid on the growth, conversion efficiency and carcass composition of Cirrhinus mrigala $(\mathrm{H})$ fry. J. World Aquac. Soc., 33: 199-204.

Vielma, J., Makinen, T., Ekholm, P. and Koskela, J. 2000. Checked the Influence of dietary soy and phytase levels on performance and body composition of large rainbow trout Oncorhynchus mykiss and algal availability of phosphorus load. Aquaculture, 183: 349-362.

Wang, F., Yang, Y. H., Han, Z. Z., Dong, H. W., Yang, C. H. and Zou, Z. Y. 2009. Effects of phytase pretreatment of soybean meal and phytase-sprayed in diets on growth, apparent digestibility coefficient and nutrient excretion of rainbow trout (Oncorhynchus mykiss Walbaum). Aquac. Int., 17: $143-157$

Wedemeyer, G. A. and Yastuke, W. T. 1977. Clinical methods for the assessment of the effects of environmental stress on fish health. Fish and Wild Life Service Technical paper 89, USDI, Washington DC, USA.

Worku, A. 2016. Moringa oleifera as a potential feed for livestock and aquaculture industry. African J. Agric. Sci. Tech., 4: 666-676.

Yan, W. and Reigh, R. C. 2002. Effects of fungal phytase on utilisation of dietary protein and minerals and dephosphorylation of phytic acid in the alimentary tract of channel catfish Ictalurus punctatus fed an all-plant protein diet. J. World Aquac. Soc., 33, 10-22. 
Yoo, G. and Bai, S. C. 2014. Effects of the dietary microbial phytase supplementation on bioavailability of phosphorus in juvenile olive flounder Paralichthys olivaceus fed soybean meal based diets. Fish Aquac. Sci., 17: 319-324.
Yuangsoi, B., Klahan, R. and Charoenwattanasak, S. 2014. Partial replacement of protein in soybean meal by moringa seed cake (Moringa oleifera) in bocourti's catfish (Pangasius bocourti). Songklanakarin J. Sci. Technol., 36(2): 125-135. 